\title{
Negotiating Socialist Lives after the Fall. Narrative Resources and Strategies of the First Socialist Generation in Bulgaria
}

\begin{abstract}
This article is based on the life stories of about 100 women and men born in the 1920s and 1930s in Bulgaria. The stories were elicited in oral history interviews enquiring into their lives under the communist regime. The starting hypothesis was that, in the absence of a shared public narrative about the socialist past, as is the case in present-day Bulgaria, people would struggle to make sense of their lives during the time of socialism and have difficulty producing meaningful autobiographical accounts. The article explores the narrative strategies the interviewees adopted to let them present their lives as meaningfully seamless and coherent, despite the change in frame of reference. Four such strategies are discussed: sameness (unbroken loyalty to the former regime); biographical revisionism (distancing the self from the regime but retaining loyalty to the ideology); reversed temporality (privileging the past); and steering away (focusing on private life while ignoring its context).
\end{abstract}

Daniela Koleva is an Associate Professor in the Department of History and Theory of Culture at Sofia University.

In this article, I offer a somewhat unorthodox take on the perennial life-and-times approach commonly used in biographical production. I examine how socialist lives have been described and justified in postsocialist times. The research was conducted within the framework of a project focusing on written and oral autobiographies of elderly Bulgarian men and women collected since the fall of the communist regime. ${ }^{1}$ Those interviewed included public figures-intellectuals, authors, former cadres of the regime, and Stakhanovite workers-but also ordinary individuals from villages and small towns, often from humble occupations and without much education. I call them 'the first socialist generation' because their active lives more or less coincided with the period of state

1 'Patterns of Anxiety: Life Stories and Narrative Models in Socialist and Postsocialist Societies' (2009-2012), funded by the National Research Fund of Bulgaria, project leader Prof. Alexander Kiossev. The comprehensive results of the research will be published in Alexander Kiossev / Daniela Koleva, eds, Trudniat Razkaz: Avtobiografični (Ne)Spraviania săs Socialističeskoto Minalo, Sofia (forthcoming). 
socialism, and their formative years, when they were in their late teens and early twenties, were during the period when the regime was established - the time from the late 1940s to the mid-1950s. The starting hypothesis of the project was that, after the total destruction of the ideological language of communism, and in the absence of a broad consensus about the socialist past in Bulgarian society, the representatives of this generation would have difficulty producing coherent meanings out of their fractured life trajectories. They would be like the builders dispersed from the Tower of Babel, confounded by a 'confusion of tongues'. Having to experience the total loss of their previous living conditions, they would not be able to come to terms with the difficult legacies of socialism and their personal experiences of 'living a lie' during that period (to quote Václav Havel). Working through all this (in the sense of Freud's Trauerarbeit and of Adorno's Vergangenheitsbewältigung) would, it was assumed, be hardly possible. For this generation - and perhaps in Bulgarian society at large - there have been no shared reference systems by which people can work out clear notions of their past lives and give them valid meanings in the context of wider society. According to the hypothesis, these difficulties should lead to a multiplication of biographical patterns and a proliferation of various narrative models in both written and oral versions. It was this that the project team set out to explore.

There are, no doubt, many differences between oral and written autobiographical accounts. These might start with the very motivation to embark on an exercise of self-disclosure, and be amplified through differing rules of genre to audiences, actual and imagined. However, there is one major similarity stemming from the administrative practice of using formal autobiography and personal files containing detailed biographical data. This practice, and the corresponding reference documents, were of the utmost importance for the communist regime in its efforts to support those social groups in the name of which (or on behalf of which) it had come to power. To attain this goal, the regime had to identify its eligible beneficiaries, as well as those it aimed to exclude. ${ }^{2}$ That is why socialist citizens had to submit autobiographies and letters of reference (unofficially called 'letters of trustworthiness') containing detailed biographical data. They had to do this at every step in their lives-for example, enrolment in an educational institution, application for membership in a political organization, starting a job, changing workplace, and advancing in career. These autobiographies were not simply reports about the events of their lives but, more importantly, they were proof of the link between individual lives and the ideological 'grand narrative'. This link was to be the core of the individuals' identities as socialist citizens. What was important for the regime was not just the existence of such a link but also the readiness of individuals to

2 On social engineering in the field of university education, see Pepka Boyadžieva, Socialnoto inženerstvo, Sofia 2010. 
forge it, to maintain it and to affirm it by each and every autobiographical act. ${ }^{3}$ No wonder, then, that the German historian Lutz Niethammer has defined the communist regime as 'biocracy' - a system of human resources management where individuals' career chances depended on their ability to furnish themselves with politically acceptable biographies. ${ }^{4}$ Hence an essential feature of both oral and written communist autobiographies, a feature largely still present, is that they are public exercises. They are closer to the ancient genre of apology than to the introspective, reflexive, self-critical 'confession', the archetype of the autobiographical genre in European culture.

But what happens to ideologically conceptualized life narratives after the demise of a regime - after the deconstruction, rejection and ridicule of the former biographical model (which was already happening in the first years of the postsocialist transition)? How do autobiographical narratives attain their goal of making a life seem meaningful, and not just a temporal, sequence of events and achievements?

The oral history projects on which this study is based were carried out at the Institute for the Study of the Recent Past in Sofia between 2007 and 2009. They aimed to give a hearing to 'voices from below', the voices of those marginal or totally absent from public discourses about the socialist past. As a result, about a hundred biographical interviews were conducted with men and women aged between 60 and 85 from selected localities: the mountain village of Bela Rečka, the city of Rousse and the smaller towns of Koprivštica, Belene and Velingrad. As a corpus, they exemplify the whole range of 'prototypes' of life experiences and attitudes. These include those who consider themselves winners or losers from the transition; those who benefited or suffered under the communist regime; and the old system's advocates and critics. An explicit focus on life under the communist regime was critical since-as is not the case in written autobiographies and memoirs - the topics introduced by the interviewers set the remit of relevance and the thematic scope of the narratives. The speakers interviewed were thus drawn in to testifying quite explicitly about their everyday lives and life courses under state socialism.

In this article I would like to take another perspective on the life stories. I am not so much interested in reconstruction of the socialist everyday as in how

3 Daniela Koleva, Umestnata Identičnost: Avtobiografiite mezdu Svidetelstvoto i Vlastta, in: Žana Damianova, ed, 'Ars inveniendi'. Izsledvania v čest na prof. Ivaylo Znepolski, Sofia 2002, 417-439.

4 Lutz Niethammer, Biographie und Biokratie, Mitteilungen aus der Kulturwissenschaftlichen Forschung 37 (1997), 370-387. I am grateful to Professor Niethammer for sharing the manuscript. For other, more public, aspects of the politics of biography in the GDR see Catherine Epstein, The Politics of Biography. The Case of East German Old Communists, Daedalus 128 (1999), no. 2, 1-30. 
the interviewees 'do things with words' ${ }^{5}$ So the question is what they actually 'do' when they tell about their lives under state socialism. I argue that, more or less successfully, they construct a desired (or at least acceptable) self-identity, lay out their worldviews, contest others' positions and defend their own. They assert their authority as witnesses, share their opinions on current issues, speak as representatives of certain groups or categories - be they generational, gender-based, local, ethnic, professional, political, or other-and send messages to imagined audiences. Most importantly, however, they review their lives from the point of view of a telos and a meaning acceptable to themselves and their circles. The pragmatist perspective I adopt makes it possible to explore how they achieve all this and to assess the narrative resources they use, albeit not always consciously. By 'narrative resources' I mean the repertoire of acknowledged, valid and commonly practised ways of constructing narratives about individual lives that are available to the members of a society or group. Although the individual is the one who remembers and weaves the story, the tale that emerges is an endeavour transcending personal experience, for personal memories are embedded in social contexts and are shaped by cultural (and in our case ideological) models that channel the sedimentation of experience into memory. Vocabularies, rituals, symbols, commemorative gestures and other practices are part and parcel of the social-cultural context providing the narrative resources. ${ }^{6}$ Furthermore, each story is conditioned by its situatedness at the crossroads of various corpuses of knowledge and various interests. In other words, the life stories are intersubjectively engendered, not only in the narrow sense of immediate interaction in the course of the interview, but in a broader sense referring to meaningful social interactions. ${ }^{7}$

Following the key hypothesis of the project, I start from the assumption that the lack of a public consensus on the socialist past in Bulgaria (unlike other postcommunist countries) makes it difficult to create a shared narrative and even a shared vocabulary for thinking and talking about it. This, in turn, leads to fragmentation of memory and difficulty in making meaningful connections between private and public, past and present, biography and history. The shattering of the reference system in which biographical narratives used to be situated and the dissipation of their accepted vocabulary have made the task of autobiographers exceptionally difficult. People recounting and assessing their life stories need to overcome this semantic crisis and find a model for making

\footnotetext{
${ }^{5}$ John L. Austin, How to Do Things with Words, ed by J. O. Urmson and Marina Sbisà, Cambridge/MA ${ }^{2} 1975$.

6 Barbara Misztal, Memory and Democracy, American Behavioral Scientist 48 (2005) no. 10, 1320-1338, 1321.

7 Graham Gardner, Unreliable Memories and Other Contingencies. Problems with Biographical Knowledge, Qualitative Research 1 (2001), no. 2, 185-204, 196-197.
} 
sense of identities straddling two different epochs separated from each other by a major historical, political, social, and semantic break. As narrators and protagonists of their own stories, they need to convince us (and themselves) of their moral integrity and see an overall meaning in their lives. This pressure for moral integrity requires them to explain if and how they remained 'true to themselves' in spite of the shift of the ideological reference systems which make personal narratives possible. Therefore, their 'biographical work' can be expected to focus on mastering the relations between two 'lives' and two different 'times' - during and after state socialism. It is these relations that are likely to require special narrative strategies to turn mere chronological sequence into logical coherence and to construct a continuity of the self. Several such strategies can be found in the life stories. In the following sections, I discuss four of them: sameness (unbroken loyalty to the former regime); biographical revisionism (distancing the self from the regime but retaining loyalty to the ideology); reversed temporality (privileging the past); and silence (focusing on private life while ignoring its context). In conclusion I return to the initial hypothesis about the postcommunist 'confusion of tongues' and the difficulty of producing coherent meanings out of fractured lives.

\section{'Not Changing Colour'. Sameness as Narrative Strategy}

Perhaps the most influential culturally established biographical model in the European tradition is the so-called Bildungsroman, whose paradigm was set by Goethe's Wilhelm Meister. Oral autobiographies are generally unlike this model, however. In them we seem to encounter mostly Odysseuses, rather than Wilhelms: the immutable self goes through various transformations, but its essence is left unscathed. The story presents an unquestioned identity of narrator and protagonist. There is no distance between them; there are no ruptures, and no reconsiderations of the individual's life path.

But how is it possible to fashion an immutable self, or to remain 'true to oneself' when one's own life project is not in harmony with societal changes? This is a challenge many interviewees have faced and they have found various ways to cope with it. One of them is the strategy of 'not changing colour', in other words, remaining loyal to communist ideas or values as a way of maintaining continuity with the former self. This loyalty always has positive connotations in interviewees' statements, especially when combined with disapproval towards those who did change their political orientation, or 'colour', after 1990. Interestingly, this is very often the stance of individuals who did not enjoy any privileges under the communist regime, like the retired agricultural worker from Belene who declared: 'I'll cast for the red one [...] the red paper, I don't know 
the white ones, I only know the red one. And I've cast, and so far I've always cast for the red one only.' A lack of orientation, of political literacy, and of any interest in the political process is thus repackaged as loyalty to the Bulgarian communist party and its successor, the Bulgarian socialist party, although the speaker has never been a member of either of them. In such cases, the interviewees think of communism not as a regime or ideology, but rather use it for self-mythologization. Personal and collective mythologies of this kind seem to signify faithfulness to a personal identity formed in the past and embody the virtue of 'being true to oneself'. There is not necessarily any real loyalty to the political party for which the interviewees say they vote. ${ }^{8}$ Here is how a retired cook from Velingrad (b. 1930) explains her choice:

'I'd rather not vote at all than cast another voting-paper, for someone else. I have lived through it, and I've built a house, and I've educated three children, three children. Oh in what need I brought them up: my mother-in-law died early, my eldest daughter was in the seventh grade, my second son in the fourth grade, the youngest in the second. We used to run around to work, and we built the house, and I gave education to the children, and wedding parties, and conscription parties [...].'

Although what she says is about the previous regime, the interviewee is actually recounting her own life achievements. Her story does not explain her voting behaviour because it has no connection with it. What we learn about 'that time' is that it was a time of need, hardships and 'running around' and this functions as a pseudo-explanation of her present political attitudes, only rhetorically linking her life history and her political position. The real explanation for her political attitudes is to be found in an earlier sentence which states that her father had been a communist ever since 1922. This 'inherited' political loyalty is seen as a virtue in itself, instrumental in forging links between the generations in her family, and between the past and the present. It is a sign of continuity and 'sameness', and hence the core of the story of her stable moral integrity. Thus 'not changing colour' turns out to be a personal moral virtue rather than a matter of real political conviction. Positions like this are most often held by interviewees with low education and unskilled occupations. Like most representatives of their generation, they regard themselves as losers from the postcommunist transition, even though they experienced no upward social mobility during the previous period.

Actual members of the former communist party articulate the loyalty motive differently: not in terms of a passive virtue, but by inscribing themselves, as agents, into the politically appropriate grand narrative. In this respect, their autobiographies sometimes seem petrified or 'musealized': the meanings and details have not changed at all. A static shaping of the self draws on the resources

8 The interviews included no questions about political preferences and voting behaviour. This information was always shared spontaneously and on the initiative of the interviewees. 
of the formal biographies required by the regime-'reliable' origin, contributions to the party and the socialist construction, 'correct' political attitudes. All these, however, are presented not as clichés but as important, personal experiences of real life, imbued with the same meanings now, just as in earlier times. These experiences not only explain the individuals' past choices, but still serve as a main point of reference for making sense of their lives. The stories of poor childhood, privation and work from an early age, of membership in the Young Workers' Union, ${ }^{9}$ or voluntary labour in youth brigades function as justifications for maintaining support for the communist regime and identification with its values of collectivism and equality:

'I was a member of the clandestine RMS in high school and I was the secretary of the class. When things changed [after the communist coup d'êtat, D.K.] I collected all Branniks' clothes and their knives, and I distributed them among our poor students. And in 1947, the first RMS recruitment, they made us party members - and up to now, now I am still a party secretary.'10 (Velingrad, male, b. 1928)

'Our tragedy after the 10th of November [1989, D.K.] is that if earlier they used some example of the Soviet Union, now - a thoroughly American way of life. [...] They created capitalism, but in the most cruel and dirty way. Now we no longer have the slogan "Man is other man's brother", or "One for all, all for one". Now we have: "Homo homini lupus est", the Latin saying [Man is like a wolf to his fellow man, from Plautus] And for twenty years only, we have re-educated the young people so that our young people have no morality, they don't know what to do. They have no aim. Now everything is calculated in money. People are also assessed in money. [...] You can't convince me that we have gone back a hundred years from the era of socialism into the era of capitalism and can be pleased [...]. You shouldn't try to convince me that now capitalism is better than socialism. Don't try, you won't convince me. (Velingrad, male, b. 1924)

James Mark has pointed out that such life stories are the result not only of political ideology but also of powerful formative experiences in the interviewees' younger years. ${ }^{11}$ They are indeed usually based on experiences of inequality, injustice, and poverty, as well as of upward social mobility under the communist regime. The latter has not always been significant in 'objective' terms - the individuals presenting their lives in this way have not always had successful careers, or changed their social milieux and ways of life-but they understood their lives in terms of serving the communist regime in order to get on. It is not possible to decide unequivocally if, and to what extent, statements like theirs

${ }^{9}$ Rabotnicheski Mladezhki Sayuz, RMS-the youth organisation of the communist party, established in 1928, clandestine from 1934 to 1944, and later renamed Komsomol after the Soviet model.

10 Brannik was a nationalist youth organisation (1940-1944), modelled on the German Hitlerjugend.

11 James Mark, The Unfinished Revolution. Making Sense of the Communist Past in Central-Eastern Europe, New Haven, London 2010, 135. 
are justifications of the regime, or of the ideology, or of a personal worldview. We are left to question to what extent the narratives are triggered by present inequalities and injustice, or by the interviewees' perception that their life experiences have been sequestered and misconstrued. It can be hypothesized that they involve an element of 'recycling', in which the representation of the past in accordance with its ideological categories now has a different meaning-a self-positioning in defiance of the dominant public discourse. Thus the past acquires a new legitimacy: it is no longer a matter of automatic general consensus but rather a personal and conscious choice, an act of resistance to a new and different consensus. The communist narrative functions in a new way-it lies at the core of a 'dissident' moral identity expressed by some interviewees as a defiant statement of their 'not changing colour'.

\section{Distancing as Narrative Strategy. Biographical Revisionism}

In Bulgaria, as in the other postsocialist countries, an avalanche of memoirs and autobiographies dealing with the recent past appeared in the years following 1989. The earliest were memoirs of victims of the regime: political prisoners, those who had stood in opposition, and those who had been in labour camps. ${ }^{12}$ As the writings accumulated, these turned out to be only a small proportion of the whole. Much more numerous and substantial were the autobiographies and memoirs of communist party functionaries, members of the managerial elite, state security officers, and intellectuals. Many of them tried to capture their readers' attention by revealing unknown facts about the functioning of the regime (some of them rather dubious); others focused mainly on their authors' personalities and life histories. In one way or another, all of them amounted to rewritten autobiographies. ${ }^{13}$ Whatever the motivation, the authors were undertaking a complex task, reconsidering not so much the facts as how to conceptualize lives no longer unproblematically inscribed into the communist project. They had to situate themselves into a new framework of meanings and values - a pluralist and democratic one.

Though unacquainted with this literature, the interviewees had been immersed in, and influenced by, what may be called 'the culture of rewriting' - the reconceptualizations and renegotiations of personal biography that continued

12 Ekaterina Bončeva et al., eds, Bulgarskiat GULAG: Svideteli, Sbornik ot dokumentalni razkazi za konclagerite v Bulgaria, Izdanie na v. demokracia, Sofia 1991; Vasil Stanilov, ed, Pisahme da se znae. Sbornik ot razkazi na svideteli v tri toma, Sofia 2007.

${ }^{13}$ On the rewritings of intellectuals' autobiographies, see Kiossev / Koleva, Trudniat Razkaz; on those of communist leaders see Roumen Daskalov, Se souvenir du socialisme. Le socialisme dans les mémoires de quelques grands fonctionnaires communistes, Divinatio 19 (2004), 41-52. 
throughout the 1990s and in the early 2000s. Its public discursive and visual forms guided personal reminiscences through recurrent themes in the media, through the circulation of certain images, through consensual notions of 'tellable' experience, and through models of its rhetorical handling. ${ }^{14}$ Just as significantly, the interviewees had been raised in the culture of 'biocracy', already described, whose basis was biographical adaptation to the regime. It is therefore not surprising that the interviewees' efforts at adapting their biographies to changing circumstances tend to follow the models established by recent elites.

Like the last group, the interviewees who deploy distancing strategies also use the legitimation resources of the communist regime to make sense of their lives. Their narratives follow its administrative-biographical models: worker origin, poor family, participation in the voluntary brigades and/or the establishment of agricultural collectives. In this way, their personal histories and family histories become entangled with the historical narrative in its communist version. Unlike the stories of the first type, however, these ones try to show that the agents' choices were morally justifiable within the historical context in which they occurred. So it is not paradoxical that the narrators again draw on the model of the past. Only, now they do so in order to explain their distancing from the communist regime: they point to its unfulfilled promises of well-being, equality and justice. They usually start by describing their family of origin where their leftist views were imbibed and through which their membership in the communist party was predestined. They continue with an account of their own activities and contributions to the building of socialism; then arrive at the moment of disappointment and their drifting away from the regime. The reasons may be different: they may cite either what the regime or its representatives did (injustice), or what they failed to do (unfulfilled promises). In many stories of this type there is also a moral paragon-a person or an idea-against which the communist reality was measured and was found wanting. The moral paragon then provides justification for the narrator's ensuing estrangement from the regime.

Here is how this model finds emplotment in the story of a woman from Rousse born in 1939:

'[...] and I remember that when the 9th September [1944, D.K.] came, my father as a worker in the workers' detachments, they would go to inspect those rich houses. And I remember how honest my father was, poor soul. He didn't bring a mote home.'

The nature of the activities performed by the workers' detachments is not questioned, nor is the legitimacy of the inspections of the 'rich houses', for the

14 Antonina Harbus, Exposure to Life-Writing as an Impact on Autobiographical Memory, Memory Studies 4 (2011), no. 2, 206-220. 
emphasis is laid on the father's moral integrity. The changes after 1944 are presented again through a child's eyes and through the intimacy of family relations:

'[...] and I often dreamed of my grandpa, that we're flying together [above the town, D.K.] and I was showing him: Look, Grandpa, you won't recognize our street, look how it is now [...], that's what I told him in my dream, so much I was happy and wanted him to know that there was a change.'

Thus family members from earlier generations end up being recruited as moral allies of the interviewee. With their approval and encouragement, she made her first steps as an activist while she was still at school; she joined the pioneer organization, knitted gloves for the soldiers with her mother, and gave her father's savings to the postwar reconstruction effort. She argues that it was not a 'political time', but there was mobilization in a common cause-to improve people's situations after the war. It should be remembered that antifascism regardless of its later political instrumentalizations - did mobilize broad social strata during, and immediately after, World War II. In this way, the ideals that came from the moral paragon are enriched with the idea of unity and uplift in the name of a common cause - an idea that is equally applicable to any moment in history ('May this happen to Bulgaria again'):

'[...] it started immediately: work, work, work, that's it. Work to rescue the homeland, the people, the cattle from hunger. [...] Nothing else. It's, I don't know, just conscientiousness. Conscientiouness. And also, we'd heard more or less about the Soviet Union, the Soviet people, this was quite an influence.'

The de-ideologization of the past and its representation in the vocabulary of collectivist ethics brings into sharp relief what can be 'rescued' from it as being of universal value and hence unquestionable. Against this backdrop, the story singles out a moment of disappointment-an injustice towards the narrator's husband brought about by his party superiors, which later led to his terminal illness and early death. But it does not lead to total alienation; the woman finds it possible to separate the 'idea' from the reality and to keep convictions intact:

‘We wanted democracy, just as we do now [sic!, D.K.] - and I wanted it too because I didn't approve of many things and they were wrong [...]. The belief - no, I believe in the idea just as I did, but the particular individuals - but he is an individual, an individual! These individuals were the ones who did the wrongs.'

This separating of ideas and individuals, of values and practices, seems to provide a way for the interviewee to explain her loyalty towards the ideal and the ideology. The biographical work supplies the link between the personal, family, and generational narrative and the legitimation narrative of the regime. Paradoxical as it may seem, it is not in the history of the communist regime itself but rather in the individual's biographical experience that the regime's legitimating values still abide. Thus personal experience is integrated with the 
political imaginary. But when this integration is destroyed (or perceived as being destroyed) it becomes possible to sever the 'pure', 'genuine' idea from its later distortion and to state a democratic and reformist position:

'Yes, and I have been a member of the communist party since the age of 22. I joined with great enthusiasm, but at that time there was purity, there were those people who had been detained in camps, harassed and who had sought justice and had restored it. That was the miracle. Later already-later, shall I say, from Todor Živkov on, when he came [to power, D.K.], things changed somehow. Things changed a lot.'

As James Mark has observed, this is not just a description of commitment to the democratic potential of communism and later disappointment; it is also an account of coming to terms with communist autobiography, which was both an instrument to advance in life and also a story through which many people of this generation understood their lives. ${ }^{15}$ Indeed, such stories are mostly told by educated interviewees whose careers suggest earlier support for the regime and sometimes-especially in their youth-active commitment to its policies. Their stories have now been undermined by the difficulties of reconciling past and present, and the need to make moral gestures in opposite directions. Safeguarding the 'ideal core' of the communist idea, disconnected from the contingent 'weaknesses' and wrongdoings of particular individuals, works as a narrative technique enabling these people to maintain a perceived immutability of the self, which again demonstrates stable moral coordinates from childhood to old age. Thus, biographical revisionism is not the result of a change of the self but rather is a response to a digression of reality from the ideal the self still cherishes.

\section{Discontinuity and Reversed Temporality as Narrative Strategy}

By a narrative strategy based on discontinuity I mean the organization of a life story around a position that can be seen as nostalgic insofar as it focuses on the past, privileging it over the present. ${ }^{16}$ This position surfaces in 'before-now' comparisons where the past is invariably praised while the present is perceived as wanting. My hypothesis is that, when this rhetorical strategy is employed in a biographical narrative, it signals a difficulty: the narrator is under the sway of discontinuity and has not mastered it. A successful biographical work forges links between past and present. Where such links are absent, this is a symptom of difficulty in meaning-making. As a result, the narrator's life is divided into

15 Mark, The Unfinished Revolution, 136.

${ }^{16}$ More on postsocialist nostalgia based on the same pool of interviews in Daniela Koleva, Hope for the Past? Postsocialist Nostalgia 20 Years After, in: Nicolas Hayoz / Leszek Jesien / Daniela Koleva, eds, 20 Years after the Collapse of Communism. Expectations, Achievements and Disillusions of 1989, Bern et al. 2011, 417-434. 
a 'genuine' or 'meaningful' phase in the past, and a 'false' or 'meaningless' one in the present. Thus discontinuity functions on a structural level in the narratives by reversing their temporality: the present is not an anticipation of the future but a loss of the past. 'Before' and 'now' suggest two worlds, rhetorically opposed to each other and separated from one another by the experience (or at least the perception) of loss.

Thus, in statements made by interviewees in this group, the socialist past appears calm and secure in terms of jobs and income, but now there is unemployment and harsh competition for jobs; the past had predictability, order, and organization, but now all one can feel is unease and threat:

'Before, we weren't afraid, we didn't lock the door, and now [...]. Now, I have a house in the country and I'm afraid to stay there. I do stay but I'm afraid. I lock the door.'

'We didn't know at home what it is to lock the house. It stayed open, the house, both entrances, you go in and out-nothing happened. And now, now, as it were, we don't leave it unlocked. Doors can't stay unlocked because it's dangerous.'

'Jobs were always at hand, always at hand. What was it that happened afterwards?, I say: How come there were jobs before and now there are no jobs?'

'[...] life was better before. For young people, life is no good now because you have no money, no job, nothing. Before, there were jobs everywhere [...].'

‘We used to live somehow calmer about the next day [...] somehow, life was better organized and you could do your best. While now you waste your energy on something totally different-the anxiety about what tomorrow will be like and what you will do tomorrow.'

The interviewees juxtapose their present impoverishment (or perception of it) against memories or notions of well-being and of a better living standard in the past. A common memory of shortages is often repackaged so as to highlight not the actual lack of goods but their potential accessibility due to lower prices:

'We did not have a lot of money then, but we had no such bills as we have to pay now.'

‘During communism, everyone could buy a car and build an apartment. Now it's difficult.'

'You have no idea what abundance means. People queued, their fridges were full. Now there is everything in the shops, fridges are empty.'

'We didn't get high salaries but there was everything in our fridge [...].'

'We were satisfied. And money we had-we grew better off, and we built houses and everything. And now - we can't get anything from anywhere!'

The loss of certain social values is the third aspect of the structural entanglement of the two temporalities defining the mood of those remembering in this 
way. Interviewees like to talk about the mutual help and solidarity in the past as opposed to their present isolation and limited social contacts. They always identify with 'the poor' - the losers of the transition - and perceive themselves as a generation under 'moral siege' insofar as the values to which they subscribe seem now to have lost their importance. ${ }^{17}$ The idea of equality, borrowed from communist ideology, has been adapted to the new situation and has assumed the form of a critique of present inequalities, above all in income and living standards. In contrast, past inequalities are systematically downplayed:

'There was [enough, D.K.] for those above, but there was [enough, D.K.] for us as well.'

'They [the communist elite, D.K.] used to be better off. But there was enough both for them and for the poor. We could afford to go on excursions, on holidays. [...] And now, a handful of people have taken everything, the others forage in the dustbins.'

'There were many things; the people were taken care of. Now nobody thinks about the people.'

'There was something very well conceived [...] that is no longer there. There was collectivism.'

'There was morality. And now this is something archaic. Concepts! Morality, valour, honour, consciousness-oh, what is this?!'

'Life was poorer but there was not this envy that has now emerged [...]. Now everything is calculated in money.'

The 'before-now' structures appear as rational comparisons between what could be enjoyed under the socialist system-employment, security, equality, social welfare - and what today has been lost. In some cases, partly at least, they are indeed valid comparisons. More often, however, the alleged comparison actually masks an affective idealization of the past where socialism is seen through the lens of domestic life-home, family, job, holidays-and the system itself, with its economic, political and social problems, is totally screened out. Thus, through selective remembering of particular aspects of the past, nostalgic reconstructions show it as it 'needs to have been', not as it actually was. This is how nostalgia works at the structural level as a function of narrative memory: it censors, it renegotiates meanings and irons out contradictions, introducing composure and 'cosiness' through a specific narrative circularity, and it engenders meanings from dychotomies and contrasts, instead of looking for more complex and multifaceted relations between past and present. ${ }^{18}$ While almost no life story appears entirely constructed in the 'nostalgic mode', the latter pops

17 Peter G. Coleman / Andrew W. McCulloch, Societal Change, Values, and Social Support. Exploratory Studies into Adjustment in Late Life, Journal of Aging Studies 4 (1990), 321-332.

18 Michael Pickering / Emily Keightley, The Modalities of Nostalgia, Current Sociology 54 (2006), no. 6, 919-941, 925. 
up very often and dominates large parts of the stories of many interviewees regardless of their social profile or current situation. Thus it appears to be a feature of generational memory rather than one linked to particular social contexts or situations.

However, alternative stories of the past sometimes disrupt the nostalgics' life narratives, in spite of the line they intend to take. Here is a woman from Bela Rečka village systematically enumerating the advantages of state socialism in comparison with the present:

'Look here, I'm not young, I was [born in, D.K.] 1937, in November. And I've lived through that period. But I should tell you that it was good. [...] I used to work, I used to stitch cardboard boxes for [an enterprise in, D.K.] Mihaylovgrad. But I used to make 400 boxes, and I'd get 40 levs. And as I go out in the afternoon in Vărshets [the nearby town, D.K.], with five levs I'd buy in the shop, so that I hardly drag it home for my children: salami, tomatoes, peppers, all kinds of food. And I can say, especially for women like me, who were alone as we were left, that management, the collectives [...]. And it was nice indeed. Holidays would come, the 9th of September, and here-a simple village but we used to have a brass band. And they'd come out and we'd go round the whole village and march in front of the school. All day long they'd play and dance [...]. Now everyone is down and only thinks how to make ends meet. If you go to a doctor, it was free. [...] And I wed my child, and I fixed the wedding, and I bought an apartment and furnished it, and my children used to live [well, D.K.].'

What follows after this introduction, however, is a story of early marriage, an alcoholic husband, and the hard work needed to raise two children, one of them chronically ill. The narrator's refusal to send her sick child to an institution started off many years of struggle with the health care bureaucracy in a battle to gain recognition of the child's disability, a pension for the child (who meanwhile came of age) and a labour readjustment for herself so she could take additional work home. The story ends with the sad conclusion: 'And when you look, there's not a day that I've really lived my life.' Thus the nostalgic idealization of the past is powerfully contested by this unexpected, and perhaps unintended, story which introduces a completely different range of circumstances:

'No, no-no life at all! The only thing that I steered away and went to [work in, D.K.] Vărshets, and got along with the women [...]; even today I feel soft-hearted for these women. We'd sit down for lunch [...]. Each of us used to bring food from home. Whatever was left from the previous evening, I'd put in a little box, I'd add some bread, and I'd sit down at lunch and eat. And they'd sit with me. Such a life did I have with them - like sisters. I'd say, better than kin. We used to get along very well. One of them has remained, all the others passed away. So this is my happy life, that I worked there. Otherwise-troubles, rows, turmoil [...].'

The testimony slips away from the interviewee's exegeses; the life story exposes itself to alternative interpretations. The earnest effort to make positive sense 
of a personal life during socialism by referring to socialism as such remains problematic.

\section{The Absence of Socialism from the Life Stories of Socialism}

Biographical researchers normally assume that 'conspicuous silences' on major historical events and situations from the stories people tell imply that the narrators somehow (and exceptionally) remained unaffected; or, more likely, that these individuals have suppressed or avoided the significance of what has happened around them. ${ }^{19}$ The absence of socialism from the life stories of our interviewees has perhaps another explanation, having to do not only with personal lives, but also with the habitus they describe. Stories of this type may exemplify ways of negotiating with the system during the later decades of socialism. At the time, it was possible for individuals to function successfully within the system while not necessarily subscribing to its principles. ${ }^{20}$ The interviewees trivialize the model socialist narrative, making it void of its normativity, of its values and meanings. This is because the teleology of their personal biographies is not oriented towards goals outside their own lives. In the retrospective glance the interviewees cast on their lives, family, home and children appear to have been the highest priorities. Women, even ones with good education and skilled jobs like doctors and accountants, often tend to employ this narrative strategy. In some other cases, men from the small towns who did not enjoy significant careers tell similar stories, in which the 'official' - ideological and institutional contexts are very distant, and seem totally irrelevant to their own lives. This narrow focus demonstrates the pragmatism of biographical knowledge: it is directed towards coping with the practicalities of the individual's lived reality. ${ }^{21}$ People seem to know, understand, remember, and value whatever they need in their everyday lives and make this paramount:

'The family - the children, to get an education. Nothing else was of interest for me [...]. Some were pleased, others not [with socialist changes, D.K.]. But I had no chance to get closer to such people. I had no chance [...] I lived a life of my own - with my husband, with the child [...].' (woman from Rousse, b. 1919)

19 Robert Miller / Robin Humphrey / Elena Zdravomyslova, Introduction. Biographical Research and Historical Watersheds, in: Robert Miller / Robin Humphrey / Elena Zdravomyslova, eds, Biographical Research in Eastern Europe. Altered Lives and Broken Biographies. Aldershot 2003, 1-24, 3.

20 See, for example, Alexei Yurchak, Everything Was Forever Until It Was No More. The Last Soviet Generation. Princeton/NJ 2005; Ivaylo Znepolski, Bulgarskiat Komunizăm: Sociokulturni Čerti i Vlastova Traektoria, Sofia 2008.

21 Gardner, Unreliable Memories, 194. 
'I used to mind my own business, my studies and that was it [...]. And I have done well. I have put together apartments for my children and I have an apartment of my own.' (man from Rousse, b. 1926)

Thus, following the approved communist narrative without resistance, these stories fundamentally change its original meaning. They reveal how the normality of everyday life deviates from the ideologically prescribed norms. Here is how one interviewee answers a question asking her to single out the most important event in her life:

'Well, what event? Everybody struggles - to work, to survive. Otherwise, otherwise what? Otherwise-you have to stay without a home, to wander around. [...] We, I'm telling you, we, everyone used to take care to feed themselves and to provide for the children.' (woman from Belene, b. 1930)

Here is another answer to the same question:

'The birth of the children, raising them, educating them. How I had no money. The elder one would come home from Svištov, already a university student, we would wonder with my wife what to give her on her way back. We were always short of money. I'd give her 10 levs, OK. The last two years she was in Svištov, the younger one in Pleven, also a student, at the teachers' institute. It's a three-year programme. So they overlapped [...]. What to do now! I get 120 levs, my wife would get $60-70$ levs from the collective. Should you buy clothes, what should you buy first? We were always short of money. It is painful not to be able to support your children.' (man from Belene, b. 1930)

The microfocus of this kind of narrative can be interpreted as a rhetorical technique enabling the speakers to distance themselves from the political context and its large-scale consequences: the personal becomes an alternative to the collective; there is biographical 'dissidence' as the individual has turned inward, and away from collective goals. This orientation bears the germ of rebelliousness. 'Flight' into the private sphere can be seen as a form of resistance in another aspect as well: memories of personal events in private life are less influenced by public cultures of memory and are relatively independent of collective memory and its politics. Thus the stories of this group can to some extent be taken as counter-narratives.

But their oppositionality - if any - is very limited. Self-projections of this kind can only be sustained if the scope of the narrative is very narrow, not going beyond the private sphere. Narratives of such a limited focus do not really undermine the communist project; they merely retreat from its consequences. ${ }^{22}$

'The important thing was that we were more or less OK, and we could, of course, buy cars, build houses and live our everyday lives happily and calmly. This was

22 Cf. Carol Wolkowitz, 'Papa's Bomb.' The Local and the Global in Women's Manhattan Project Personal Narratives, in: Molly Andrews et al., eds, Lines of Narrative. Psychological Perspectives, London, New York 2000, 104-116, 104-105, 114. 
what was important for us as a small provincial town here, far from the turmoil. This was important for us, and it was nice and calm [...]. This is how we used to live-our lives, they used to live their lives [...]. But we never had such claims, to fly high, to show ourselves, to-to play the boss and the like [...]. So, we were pleased with what we had [...]. I am pleased with my life. Don't know about the others.' (woman from Belene, b. 1941)

Here, as she presents it, the narrator's life 'coincides' with the regime without her even being aware of it. This statement was made by one of the youngest participants in the survey, suggesting that for her generation this 'coincidence' was already given by default. It can be hypothesized that the retreat into the private sphere was a life strategy actually practised (especially by later generations) and not just a resort adopted in the narrative. Alternatively, steering away from the historical and political context of private life during the interview can be a tacit refusal to share, a kind of silence. It can be a form of inauthenticity too: the tactic of people who just 'mind their own business' and, like Havel's greengrocer, 'are on good terms with everyone' but living a lie. In the course of the interviews, certain negative reactions and silences could be expected, often camouflaged by general statements like the following reply to the question, 'What impressions did Soviet soldiers leave with you?':

'Look here, I have no bad impressions of people in general because I have always been a hard worker and have managed to find something in common with everybody and to live with them like humans, so to say. These people who don't like to work, who are lazy - there are people like this now as well-they don't want to work, don't want to make any effort, but it won't do. And I, I'm telling you, I'm 80 -ever since I have memories of myself, I've always been working. And I've achieved a lot, but always due to my work. That is why I'm walking with a stick now [...].' (man from Rousse, b. 1927)

All in all, the stories from this group could be seen as structural amnesia: the interviewees choose to forget those elements of the past no longer meaningfully connected to the present. At the same time, like the 'recycled' narratives and the narratives based on discontinuity, silence about socialism may be a form of resistance to giving socially acceptable, 'correct' answers (from today's standpoint) to the questions raised about the past.

\section{Conclusion}

Contrary to the expectations held at the start of the project, we did not discover the discursive chaos of a new Babel after the implosion of the language of communist ideology, which, however empty and hollow, was the only public narrative norm before 1989. Instead of an endless plurality of idiolects and idiosyncrasies, we found relatively few and relatively stable recurrent narrative patterns. If biographical work is a struggle against contingency and a search for 
meaning, the interviews revealed at least four narrative strategies effectively employed in this struggle, although the narrators may have been hardly aware of them. Unproblematically, the autobiographers who did not 'change colour' situated their stories in the ideological grand narrative of the communist regime, and, in the new circumstances this acquired an air of protest. The 'revisionist' autobiographers reconsidered the past from the point of view of the universal values they claimed to have kept throughout their lives. The nostalgics stylized the past metonymically; and those who retreated in their private lives trivialized the historical narrative and reduced all they were concerned with to the everyday, disregarding the broader context.

In the first case, self-identity, or 'being true to oneself', was not problematized but taken for granted. Its consistency was maintained through loyalty towards the ideology and the regime. Even though the outlook may seem 'petrified', this position is worth attention since it reflects the interviewees' resistance to present-day neoliberal values and realities.

In the second case, a more dynamic position was taken, as the autobiographers defended what seem to be universal moral values. At the same time, however, their narratives sought to highlight the democratic potential of the past through an identification with its ideals rather than its realities. There might be an identification with the early years of the regime, seen as a period of uplift and construction, rather than with later totalitarian repressions. Alienation from the regime in its later decades was often presented as resulting from loyalty to the ideal and values from which the reality diverged. In this stance, biographical revisionism also relies on self-identity and continuity, but here 'being true to oneself' means identification with the ideal and retreat from the repercussions of its (allegedly erroneous) enactment. The universal values against which the past is measured, turn out to be lacking in the present as well-an inference that indirectly contributes to the normalization of the socialist past.

The third type of life story, based on discontinuity and acute awareness of an opposition between past and present, can also be interpreted as a moral position-one of criticism and protest against the postcommunist transition and its outcomes. But precisely because it is packaged as nostalgia, this criticism is trivialized, as Gerald Creed has convincingly argued. ${ }^{23}$ The nostalgic idealization of the past can best be seen as an oblique articulation of present anxieties. ${ }^{24}$

${ }^{23}$ Gerald W. Creed, Strange Bedfellows. Socialist Nostalgia and Neo-Liberalism in Bulgaria, in: Maria Todorova / Zsuzsa Gille, eds, Post-Communist Nostalgia, New York, Oxford 2010, 29-45.

${ }^{24}$ A similar argument related to a different case is developed in Joan Sangster, Telling Our Stories. Feminist Debates and the Use of Oral History, in: Robert Perks / Alistair Thomson, eds, The Oral History Reader, London, New York 1999, 87-100. 
Finally, the focus on private life with no links to the broader social and historical context, can be interpreted as a withholding of any decision to back or reject that context. Whether such a decision has never been made or whether the interviewees refrain from sharing it remains an open question. In any case, isolating private life from the contexts of its becoming and its narrating seems to amount to a refusal to accept that continuity and change are both individually and collectively relevant.

Attention in this study has been focused on local and individual interpretations rather than official/institutional ones. The starting hypothesis was that the latter were unconvincing or altogether lacking, thus hindering the production of meaning in individual biographies. But the question of creating a coherent autobiographical narrative, of coping with ambivalences, of harmonizing different temporalities, of situating personal biography into its historical and social context is actually a question of understanding memory as a public - moral and political - practice through which civic subjectivities are confirmed or contested. Analysis of the biographical interviews with representatives of the first socialist generation revealed a seemingly solid and steadfast narrative identity without articulate signs of problematizing, reconsideration, or anxiety about personal integrity. This model was hardly possible for later generations to maintain. The narratives demonstrated the persistence of semi-official, semi-public or quasipublic ideas of what a 'normal life' and a 'normal life course' should be like, but these were now recycled and revamped according to their new context and new functions. Interviewees constructed and performed their stories so as to support the idea of 'being true to themselves'. The selective construction of the individuals' former selves and selective reconstruction of their previous lives reinforced and validated each other. Past choices were not problematized, lost chances were seldom mentioned, alternative directions not followed. 'Being true to oneself' grew from a narrative strategy into a self-affirmative moral position. Inner struggles and anxieties were either consciously hidden or unconsciously repressed, so that only isolated symptoms broke the smooth surface of the narrative to signal the existence of such struggles and difficulties. These might be defiant 'bravado' positions or reconciliatory rhetorical gestures; negative undertones in the stories of the good life in the past; steering away from questions that evoked hesitation. Finally, it should be remembered that we can only speculate about what has been left unsaid.

Thus the starting hypothesis has to be reconsidered. The interviewees' stories about socialist lives did not seem to be plagued with anxieties and difficulties. On the contrary, in most cases the autobiographers were able to marshal the narrative resources available to them with considerable success. People's ability to work through the difficult legacies of socialism could not be tested in the course of the project, simply because a need for such coping was seldom visible. 
It turned out that the first socialist generation did have some shared reference systems to confer socially valid meanings on their lives. It is true that they were only valid within relatively closed real or imagined communities-family and kin, local, professional, political, ethnic, generational, and experiential groups, and so on-but they were nevertheless in place, to a greater or lesser degree. Instead of being confounded by a 'confusion of tongues' and a multiplication of biographical narratives, the interviewees had found a few discernible patterns enabling them to speak about the recent past. These included nostalgic and ironic narratives, defensive and defiant ones, archaic and nationalist versions, mythologization of a personal past or tender sentimentalization of it, and the normalizing or demonizing of socialism. ${ }^{25}$ So it seems that the disorientation and lack of anchoring points from which to make sense of the recent past does not confuse at the level of individual biography, but is more a feature of social memory. At first glance, this may look like a healthy democratization of memory, especially when those who recollect today are compared with the 'blue' (anticommunist) and 'red' (ex-communist) 'tribes' of the early 1990s. I would caution against such a hasty optimism, however. Democratization presupposes a plurality of actors and positions, representing different communities and groups, voicing different experiences, and defending different interests. But they must start from a common ground, following commonly accepted procedures and moving in a common direction. In other words, they must talk to each other. In present-day Bulgaria the actors seem to be talking past each other.

Unlike other postsocialist countries, Bulgarian political elites have adopted a hesitant approach towards the country's socialist past. Trials against former communist leaders failed, lustration laws have been applied only on a very limited scale, and the question of secret police files has been repeatedly instrumentalized for political purposes. Though the archives were declassified and made available for research, the Bulgarian state has not deemed it necessary to establish a research institution to study communism. Commemoration of its victims has remained largely limited to the sporadic activities of political and civic organizations, and monuments to these unfortunates have been left to the discretion of local authorities in response to public initiatives. Unlike the Baltic states and some Central European countries, where anticommunism fitted easily into the new national narrative of Soviet oppression, Bulgaria has no consensual narrative of what communism was, and how society ought to come out of it now that it is no longer there. Recent history is not taught at school; no museum of communism has been established; and public interest in the communist era seldom goes beyond historians' debates. This 'politics of avoidance' has effectively precluded the working out of a common framework

25 See the individual studies in Kiossev / Koleva, eds, Trudniat Razkaz, and especially Alexander Kiossev's introductory and concluding chapters. 
for debate about the recent past. ${ }^{26}$ What we see looks more like a discursive archipelago whose islands are isolated from each other and mutually hostile. They have incommensurable ethics and non-negotiable versions of the past, each busy with its own 'collective production of historical innocence', ${ }^{27}$ which includes a projection of political responsibility onto others.

\section{CORRESPONDING AUTHOR}

Daniela Koleva St Kliment Ohridski University of Sofia, Faculty of Philosophy,

15 Tzar Osvoboditel blvd., 1504 Sofia. E-mail: koleva@phls.uni-sofia.bg

${ }^{26}$ Nikolai Vukov, The Museum of Socialist Art in Sofia and the Politics of Avoidance, Forum 'Cultures of History', without date, http://www.cultures-of-history.uni-jena.de/exhibiting-20th-century-history/bulgaria/the-museum-of-socialist-art-in-sofia-and-the-politicsof-avoidance/.

27 Wulf Kansteiner, Memory, Media and Menschen. Where Is the Individual in Collective Memory Studies?, Memory Studies 3 (2010), no. 1, 3-4, 3. 